AperTO - Archivio Istituzionale Open Access dell'Università di Torino

\title{
LUX-Lung 7: is there enough data for a final conclusion?
}

\section{This is the author's manuscript}

Original Citation:

Availability:

This version is available http://hdl.handle.net/2318/1603118

since 2016-10-17T14:12:51Z

Published version:

DOI:10.1016/S1470-2045(16)30116-4

Terms of use:

Open Access

Anyone can freely access the full text of works made available as "Open Access". Works made available under a Creative Commons license can be used according to the terms and conditions of said license. Use of all other works requires consent of the right holder (author or publisher) if not exempted from copyright protection by the applicable law. 
This Accepted Author Manuscript (AAM) is copyrighted and published by Elsevier. It is posted here by agreement between Elsevier and the University of Turin. Changes resulting from the publishing process - such as editing, corrections, structural formatting, and other quality control mechanisms - may not be reflected in this version of the text. The definitive version of the text was subsequently published in LANCET ONCOLOGY, 17 (7), 2016, 10.1016/S1470-2045(16)30116-4.

You may download, copy and otherwise use the AAM for non-commercial purposes provided that your license is limited by the following restrictions:

(1) You may use this AAM for non-commercial purposes only under the terms of the CC-BY-NC-ND license.

(2) The integrity of the work and identification of the author, copyright owner, and publisher must be preserved in any copy.

(3) You must attribute this AAM in the following format: Creative Commons BY-NC-ND license (http://creativecommons.org/licenses/by-nc-nd/4.0/deed.en), $10.1016 /$ S 1470-2045(16)30116-4

The publisher's version is available at:

http://linkinghub.elsevier.com/retrieve/pii/S1470204516301164

When citing, please refer to the published version.

Link to this full text:

http://hdl.handle.net/2318/1603118 


\section{LUX-Lung 7: is there enough data for a final conclusion?}

We read with great interest the publication of the LUX-Lung 7 trial, $^{1}$ comparing afatinib and gefitinib as first-line treatment of patients with advanced non-small-cell lung cancer with common EGFR mutations. As a general rule, in settings where more than one drug is available for the same treatment indication, a direct comparison is always useful. However, we believe that in the case of LUX-Lung 7, a complete evaluation of the comparison would need more details than those available in the publication in The Lancet Oncology.

First of all, final results of overall survival should have been presented within the primary publication. Albeit progression-free survival has been widely accepted as an endpoint in the first-line setting of patients positive for EGFR mutations [A: correct edi of EGFR mutation positive cases?], overall survival was chosen by the authors as a coprimary endpoint together with progression-free survival and time-to-tre ${ }^{\text {nt failure. }}$ Therefore [A: edit ok: definitive interpretation of the results should be based on all coprimary endpoints.

Furthermore, the interpretation of the time-to-treatment failure advantage described in favour of afatinib is quite difficult, not only because of the open-label design of the trial, but also because of the absence of details about characteristics of disease progression in the two groups. In this setting, tyrosine-kinase inhibitors are commonly administered beyond the formal definition [A: do you mear determination or assessment?] of progression, especially in asymptomatic patients with oligo-progressive disease. ${ }^{2}$ The longer time-to-treatment failure reported in patients treated with afatinib versus gefitinib compared with the negligible difference between groups in median progression-free survival documents a higher amount of treatment beyond progression with afatinib than with gefitinib. It would be of interest to see if this disparity in the administration beyond progression could be justified by different characteristics of disease at the time of progression according to the Response Evaluation Criteria in Solid Tumors. For instance, a significant difference in the proportion of symptomatic patients, as well as a significant difference in the number of progressing metastatic sites, or in the volumetric burden of progression, would represent a reasonable explanation for the time-to-treatment failure difference. Unfortunately, this information was not available in the publication. Additionally, the difference in median progression-free survival in favour of afatinib was very small ( 0.1 months) and clinically negligible.

In conclusion, based on the LUX-Lung 7 data published to date, it eems to us premature to claim that fatinib has definitely proven to be superior to gefitinib in this setting.

2 received personal fees from Boehringer Ingelheim and AstraZeneca, not related to this Comment. AA declares no competing interests.

Massimo Di Maio, *Alfredo Addeo alfredo.addeo@uhbristol.nhs.uk

Department of Oncology, University of Turin, Mauriziano Hospital, Italy (MDM); Bristo cancer institute, Bristol, Somerset, UK (AA) [A: please provide a postcode]

1 Park K, Tan EH, O'Byrne K, et al. Afatinib versus gefitinib as first-line treatment of patients with EGFR mutation-positive non-small-cell lung cancer (LUX-Lung 7): a phase 2B, open-label, randomised controlled trial. Lancet Oncol 2016; published online April 12. http://dx.doi.org/10.1016/S14702045(16)30033-X

2 Park K, Yu C), Kim SW, et al. First-line erlotinib therapy until and beyond response evaluation criteria in solid tumors progression in asian

patients with epidermal growth factor receptor mutation-positive non-small-cell lung cancer: the ASPIRATION Study. JAMA Oncol 2016; 2: 305-12. 